DOI: https://doi.org/10.35961/jppmkepri.v1i2.275

\title{
Pemahaman Masyarakat Terhadap Fatwa MUI Dan Edaran Pemerintah Tentang Shalat Jamaah Dan Jumat di Rumah Kecamatan Tanjungpinang Timur
}

\author{
Abd Malik Munir ${ }^{1 *}$, M. Kafrawi ${ }^{2}$, Fajar Tresna Utama ${ }^{3}$, Nur Ikhlas ${ }^{4}$, Maisaratil Husna ${ }^{5}$ \\ 1, 2, 3, 4, 5 STAIN Sultan Abdurrahman Kepulauan Riau, Bintan, Kepulauan Riau, 29123, Indonesia \\ *alexmuslih84@gmail.com
}

\begin{abstract}
Abstrak
Akhir tahun 2019 muncul varian virus yang meluluhlantakan dunia, virus itu disebut covid-19. Virus itu muncul pertama kali di wilayah Cina, virus tersebut memasuki wilayah Indonesia sekitaran bulan maret 2020 sebagaimana yang disampaikan oleh Presiden Jokowi. Memasuki awal mei pemerintah melakukan tindakan lockdown dibeberapa daerah dan pembatasan aktivitas ditempat keramaian. Salah satu yang dibatasi adalah aktivitas peribadatan yang dilakukan di masjid. Pembatasan ini tentu memerlukan penyesuaian, sebab tidak semua masyarakat mengerti dan menerima alasan pembatasan ini, apalagi ini terkait masalah peribadatan. Pemahaman masyarakat akan pembatasan ini terkadang masih berbenturan dengan keyakinan mereka, bahwa masalah peribadatan di masjid adalah kewajiban yang mutlak dengan meniadakan faktor kehatian-hatian kepada penyebaran virus. Majelis ulama Indonesia (MUI) mengeluarkan fatwa terkait masalah ibadah ini melalui fatwa no 14 tahun 2020. Pengabdian ini bertujuan untuk mengetahui resepsi masyarakat terkait fatwa tersebut dengan menggunakan teori resepsi yang dikembangkan oleh Ahmad Rofiq, sekaligus memberikan pemahaman kepada masyarakat terkait fatwa tersebut. Dengan harapan masyarakat dapat memahami fatwa tersebut dan melaksanakan sebagai upaya penecegahan penularan virus ini dalam rangka membantu tugas pemerintah.
\end{abstract}

Kata kunci: Covid-19; fatwa MUI; resepsi fatwa.

\begin{abstract}
At the end of 2019, a virus variant emerged that devastated the world, the virus was called covid-19. The virus first appeared in the territory of China, the virus entered the territory of Indonesia around March 2020 as stated by President Jokowi. Entering early May, the government implemented lockdown measures in several areas and restricted activities in crowded places. One of the restrictions is the worship activities carried out in the mosque. This restriction certainly requires adjustment, because not all people understand and accept the reason for this restriction, especially since it is related to worship issues. The public's
\end{abstract}


understanding of this restriction sometimes still clashes with their belief that the issue of worship in the mosque is an absolute obligation by eliminating the precautionary factor for the spread of the virus. The Indonesian Ulema Council (MUI) issued a fatwa related to this worship issue through fatwa no. 14 of 2020. This service aims to find out the public reception related to the fatwa by using the reception theory developed by Ahmad Rofiq, as well as providing understanding to the public regarding the fatwa. It is hoped that the public can understand the fatwa and implement it as an effort to prevent the transmission of this virus in order to assist the government's work.

Keywords: Covid-19; MUI fatwa; fatwa reception

\section{Pendahuluan}

Dunia dikejutkan oleh virus yang mematikan, lebih satu bulan berlalu, negara kita dilanda serangan virus yang bersifat pandemi. Virus ini tidak hanya menyerang negara kita bahkan seluruh dunia, kemunculan virus ini berdasarkan jejak media yang ditelusuri menyebutkan bahwa kemunculannya pertama kali di daerah di Wuhan Provinsi Hubei China, awalnya pasien yang teridentifikasi virus adalah tanggal 17 November 2019 dan mulai menyebar secara luas mulai desember 2019. (Kumparan, 2020)

Adapun untuk sekala Indonesia sendiri berdasarkan penelusuran secara resmi Presiden Republik Indonesia Ir. Joko Widodo mengumumkan tanggal 2 maret 2020, saat itu Presiden mengumumkan ada dua orang yang terindikasi virus covid-19, (Kompas, 2020) maka ketika itu juga Indonesia menyatakan perang terhadap corona atau Covid-19 dan pemerintah mengajak untuk warganya selalu membiasakan hidup sehat. Walaupun hal itu masih bersikap himbauan, namun setelah melihat grafik angka bertambahnya pasien covid19, beberapa pemerintah daerah seperti Kota Solo, Provinsi DKI dan Provinsi Jawa Barat, mengambil sikap sigap yaitu dengan melakukan upaya pencegahan yaitu social distancing atau disebut juga physical distancing, pemerintah kota-kota tadi membuat aturan proses belajar untuk satuan Pendidikan dilaksanakan dari rumah ( learning from home) bahkan untuk peribadatan pun dilakukan di rumah. Tak ketinggalan secara nasional mengikuti jejak tersebut misalnya kementerian pendayagunaan aparatur negara dan reformasi birokrasi (PENPAN-RB) mengeluarkan surat edaran no. 19 tahun 2020 tentang penyesuaian sistem kerja aparatur sipil negara dalam upaya pencegahan penyebaran covid-19 di lingkungan instansi pemerintah (JDIH, 2020) yang menerangkan bahwa ASN bekerja dari rumah.

Adapun untuk pembatasan di wilayah peribadatan sendiri, khususnya yang ingin diberlakukan bagi umat Islam pemerintah pusat dan daerah terlebih dahulu berkonsultasi dengan majelis ulama Indonesia (MUI), suatu wadah berkumpulnya orang-orang yang dipandang memiliki kemampuan di bidang agama. Hal ini jelas adalah upaya untuk menanyakan sebuah perkara kepada ahlinya, dalam masalah umat beragama khususnya Islam tentu ahlinya adalah para ulama, hal ini selaras dengan firman Allah dalam surah al-Nahl ayat 43 dan al-Anbiya ayat 7 :

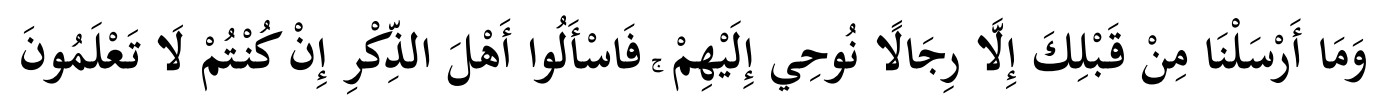

"Dan Kami tidak mengutus sebelum kamu, kecuali orang-orang lelaki yang Kami beri wahyu kepada mereka; maka bertanyalah kepada orang yang mempunyai pengetahuan jika kamu tidak mengetahui". ( al-Nahl: 43) 


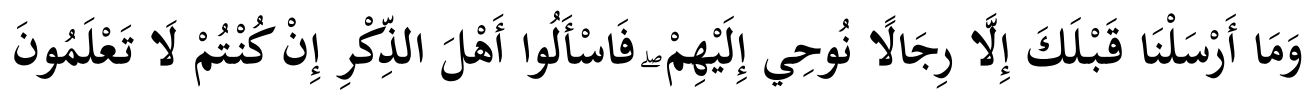

"Kami tiada mengutus rasul rasul sebelum kamu (Muhammad), melainkan beberapa orang-laki-laki yang Kami beri wahyu kepada mereka, maka tanyakanlah olehmu kepada orang-orang yang berilmu, jika kamu tiada mengetahui”. (al-Anbiya: 7)

Dalam ayat 43 surat an-Nahl Allah mengajak kaum Quraish untuk bertanya kepada umat terdahulu darikalangan ahlul kitab, bahwa Nabi ataupun seorang rasul itu pastilah dari kalangan manusia, dan jangan kamu mengira ira sekira kamu tidak mengetahui. (Al-Sabuni, 2001, hal. 11) Demikian juga untuk ayat 7 surat al-Anbiya Allah juga menyuruh penduduk Mekkah untuk menanyakan kepada orang yang berpengetahuan Taurat dan Injil apakah rasul-rasul yang datang kepada mereka itu dari bangsa manusia ataukah malaikat sekiranya kamu tidak mengetahui, (Al-Sabuni, 2001, hal. 234) dari sini diketahui bahwa ketika seseorang atau kelompok tidak mengetahui suatu perkara maka hendaklah ia bertanya kepada yang lainnya yang tahu akan perkara tersebut.

Nabi Muhammad SAW mengingatkan dalam hadisnya:

"Telah menceritakan kepada kami [Muhammad bin Sinan] telah menceritakan kepada kami [Fulaih bin Sulaiman] telah menceritakan kepada kami [Hilal bin Ali] dari ['Atho' bin yasar] dari [Abu Hurairah] radhilayyahu'anhu mengatakan; Rasulullah shallallahu 'alaihi wasallam bersabda: "Jika amanat telah disia- siakan, tunggu saja kehancuran terjadi." Ada seorang sahabat bertanya; 'bagaimana maksud amanat disia- siakan?' Nabi menjawab; "Jika urusan diserahkan bukan kepada ahlinya, maka tunggulah kehancuran itu. (Hadits Bukhari Nomor 6015.)

Berkaca dari tuntunan agama diatas maka pemerintah menanyakan tentang perihal physical distancing dalam masalah peribadatan kepada majelis ulama Indonesia (MUI), melihat perihal keadaan covid-19 yang semakin hari semakin meluas, maka terbitlah beberapa fatwa yang mengatur peribadatan umat Islam semasa merabahnya Covid-19 diantaranya adalah terbitnya fatwa MUI no 14 tahun 2020 tentang penyelenggaraan ibadah dalam situasi terjadinya wabah Covid-19, (MUI, 2020) fatwa lain yang terbit adalah fatwa No. 17 tahun 2020 tentang pedoman kaifiat shalat bagi tenaga kesehatan yang memakai alat pelindung diri (APD) saat merawat dan menangani pasien Covid-19, fatwaberikutnya adalah fatwa No. 18 tahun 2020 tentang pedoman pengurusan jenazah (tajhiz al-janai'z) muslim yang terinfeksi Covid-19. Pengabdian kepada masyarakat (PKM) kali ini kami hanya memfokuskan kepada fatwa MUI No. 14tahun 2020.

Selaras dengan Majelis Ulama Indonesia (MUI) Pusat, MUI Provinsi Kepulauan Riau meneruskan fatwa No. 14 tahun 2020 dengan membuat taushiyah tertanggal 25 maret 2020 dalam taushiyahnya itu MUI Kepulauan Riau pada poin ketiga menyampaikan agar kaum muslimin di wilayahnya tidak melakukan shalat jum'at dan menggantikannya dengan shalat zuhur di rumah, pada poin keempat agar kaum muslimin tidak melaksanakan shalat berjamaah di masjid dan menggantinya di rumah dan pada poin keenam agar kaum muslimin tidak mengadakan acara keagamaan baik itu masjid maupun mushalla.

Dalam pengamatan kami sementara, masih ada masjid ataupun mushalla mengadakan shalat berjamaah dan shalat jum'at di masjid ada juga yang masih mengadakan kegiatan keagamaan, tentu hal ini sangat berbahaya karena salah satu faktor yang menyebabkan tertular seseorang adalah karena berada di kerumunan orang.

Maka inilah yang menjadi latar belakang kami dalam pengabdian ini, yaitu kami ingin mengetahui apakah para pengurus masjid dan mushalla tersebut sudah mengetahui akan fatwa dan taushiyah dari MUI tersebut? Kalau mereka mengetahui tapi tidak melaksanakannya, faktor apa yang menyebabkannya? Dan 
memberikan pemahaman serta nilai edukasi terhadap fatwa MUI dan anjuran pemerintah terkait upaya pencegahan Covid-19.

Adapun yang menjadi tujuan dalam pengabdian ini diantaranya adalah:

1. Memberikan pemahaman kepada masyarakat tentang fatwa MUI dan edaran-edaran pemerintah tentang shalat jamaah dan shalat Jumat di rumah

2. Untuk mengetahui persepsi masyarakat terhadap fatwa dan taushiyah MUI

3. Membantu program pemerintah dalam upaya pencegahan penyebaran Covid-19

\section{Metode}

Pengabdian kepada masyarakat ini menggunakan metode Community-based Research (CBR) yaitu penelitianbersama masyarakat untuk mengatasi permasalahan yang dialami oleh masyarakat. Dalam hal ini pelaku utama pengabdian adalah tim pengabdi, pengurus masjid dan jamaah sebagai entitas kelompok penyelenggara kegiatan peribadatan di masjid.

Dalam hal ini, peneliti ataupun pengabdi melakukan transfer pengetahuan yaitu membagi informasi antara peneliti dan komunitas partner. Penggunaan metode CBR sangat memungkinkan adanya kerjasama tim pengabdi dengan komunitas dampingan dalam melakukan setiap tahapan penelitian. Mulai dari rancangan awal pengabdian, pengumpulan data dan analisis data, pelaksanaan kegiatan pengabdian atau aksi sampai diseminasi hasil pengabdian.

Berdasarkan pendapat Joannna Ochocka, terdapat empat dalam penelitian CBR yaitu: laying foundation; peletakan dasar, research planing; perencaan penelitian, information gathering and analysis; pengumpulan dan analisis data, acting on finding; aksi atas temuan (Muhid dkk, 2018) secara gamblangnya bisa dilihat berdasarkan bagan di bawah ini:

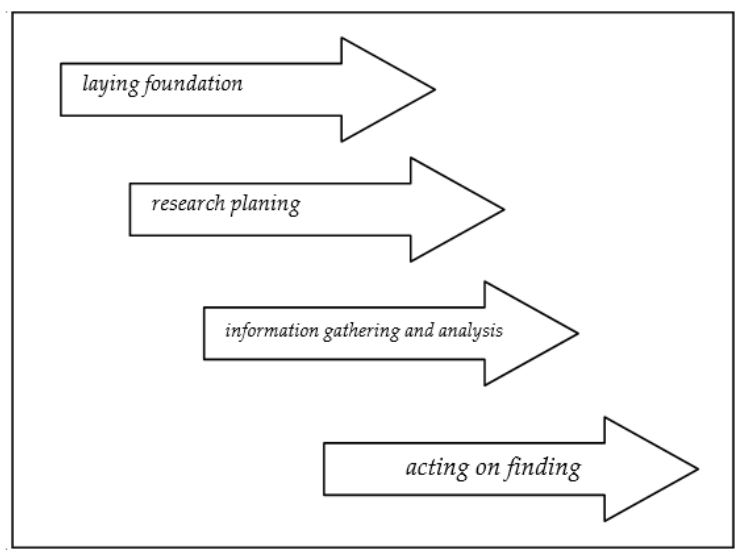

Gambar 1. Bagan tahapan CBR yang dimodifikasi tim pengabdi

Berdasarkan empat tahapan tersebut, secara sistematis penerapannya dalam pengabdian ini adalah sebagai berikut:

Pertama, laying foundation; peletakan dasar. Tahapan ini merupakan tahapan awal dalam pengabdian, mencakup studi pendahuluan tim pengabdi ke beberapa masjid di kecamatan Tanjung Pinang Timur. Pemilihan masjid ini dilakukan secara random dengan memperhatikan lingkungan yang terdekat dengan tim pengabdi, hal ini bertujuan agar proses pendampingan dapat dilakukan dengan maksimal mengingat situasi pandemi covid-19. Dari hasil studi awal ini terpilihlah 10 masjid yang ada di kecamatan Tanjungpinang Timur diantaranya adalah: Masjid Sya'arillah, Masjid Al-Hidayah, Masjid Nurul Ikhwan, 
Masjid al-Khoir, Masjid al-Barokah, Masjid Sabilul Rasyad, Masjid Ittihad, Masjid Besar Uswah, Masjid Nurul Islam, Masjid Mustaqim.

Setelah mendapatkan nama-nama serta lokasi yang dijadikan tempat pengabdian selanjutnya tim bergerak melakukan komunikasi dan konsilidasi dengan pengurus masjid melalui via whatsapp dan bertemu langsung menyampaikan perihal pengabdian ini. Seluruh pengurus yang diajak berkomunikasi menyambut baik perihal ini.

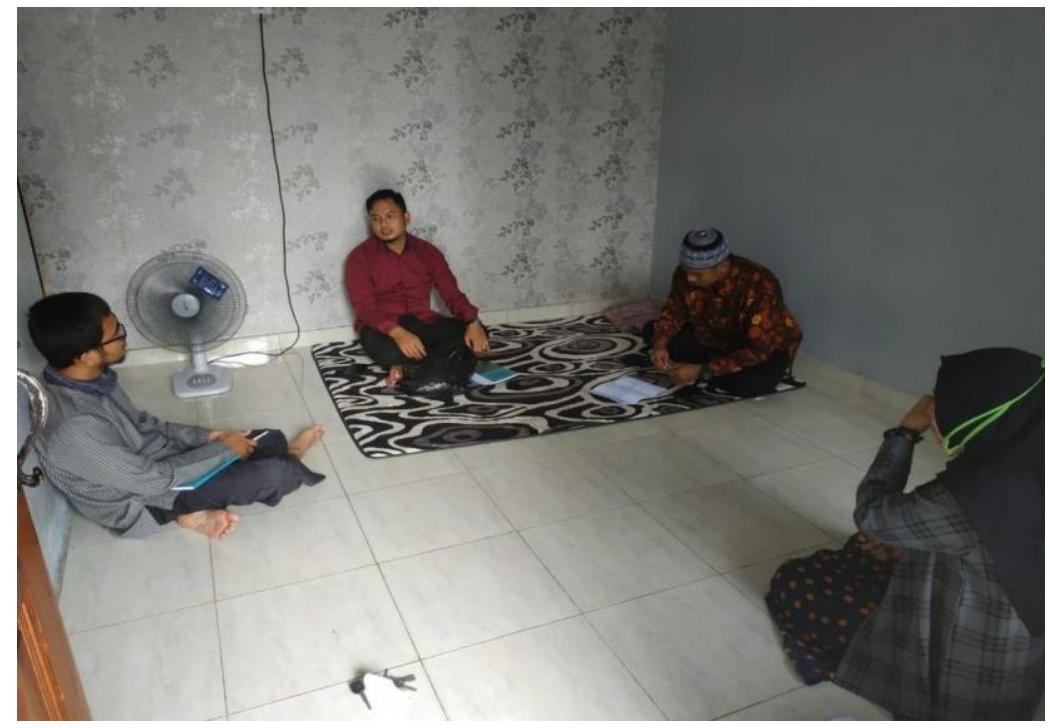

Gambar 2. Persiapan tim pengabdian

Kedua, research planning; perencanaan penelitian. Dalam tahapan ini tim pengabdi mulai memaparkan secara terperinci mengenai kegiatan ini, tim pengabdi mulai melakukan rapat internal terkait teknis pelaksanaan, dari hasil rapat didapatkan bahwa tim akan membuat draf pertanyaan terlebih dahulu untuk menggali pengetahuan pengurus masjid terkait fatwa MUI No. 14 tahun 2020 terkait penyelenggaraan ibadah dalam situasi terjadinya wabah Covid-19 serta aturan pemerintah terkait hal ibadah.

Ketiga, information gathering and analysis: pengumpulan dan analisis data. Setelah membuat draf pertanyaan serta merencanakan masa penelitian, masa pengumpulan data dimulai dari tanggal 5 mei sampai 11 mei 2020, berupa turun lapangan ke masjid dan melakukan wawancara dengan pengurus masjid yang sudah ditentukan pada masa research planning.

Keempat, action on findings; aksi atas temuan. Tahapan terakhir merupakan tahap pelaksanaan, proses dialog terjadi antara pengabdi dengan pengurus masjid terkait penyelenggaraan ibadah dalam situasi terjadinya wabah covid- 19 serta terkait aturan pemerintah tentang hal ibadah, pengabdi juga menyerahkan cendramata berupa buku yang berjudul "Fikih Pandemi, Beribadah di Masa Wabah" yang ditebitkan oleh NUO Publishing tahun 2020. Buku tersebut juga menerangkan secara ringkas tentang aturan beribadah dimasa wabah. Selain itu menyerahkan cendramata buku, pengabdi juga mencopikan fatwa MUI no 14 tahun 2020, tausiyah MUI Provinsi Kepulauan Riau tertanggal 25 Maret 2020, tausiah dewan masjid Indonesia (DMI) kota Tanjungpinang No. 004 tahun 2020 terkait pelaksanaan ibadah untuk mengantisipasi covid-19 di kota Tanjung Pinang dan terakhir surat edaran Walikota Tanjungpinang No. 440 tahun 2020 tentang himbauan pencegahan penyebaran covid-19 di masjid, surau dan mushalla.Dalam melihat pemahaman dan pelaksanaan fatwa MUI ini, peneliti sekaligus pelaku pengabdian melakukan eksprerimen sosial dengan menggunakan teori resepsi yang dikembangkan dari Jausz dan Iser tumpuan teori resepsi adalah di tangan pembaca (reader) fatwa MUI tersebut. Karena peneliti menganggap bahwa fatwa MUI itu adalah berupa teks. 


\section{Hasil dan Pembahasan}

\section{Pengertian dan Sejarah Perkembangan Teori Resepsi}

Resepsi sastra merupakan aliran sastra yang meneliti teks sastra dengan mempertimbangkan pembaca selaku pemberi sambutan atau tanggapan. Dalam memberikan sambutan dan tanggapan tentunya dipengaruhi oleh faktor ruang, waktu, dan golongan sosial (Sastriyani, 2001).

Resepsi berasal dari bahasa Latin yaitu recipere yang diartikan sebagai penerimaan atau penyambutan pembaca (Ratna, 2009, hal. 22). Dalam arti luas resepsi diartikan sebagai pengolahan teks, cara-cara pemberian makna terhadap karya, sehingga dapat memberikan respon terhadapnya. Respon yang dimaksudkan tidak dilakukan antara karya dengan seorang pembaca, melainkan pembaca sebagai proses sejarah, pembaca dalam periode tertentu (Walidin, 2007).

Menurut Pradopo yang dimaksud resepsi adalah ilmu keindahan yang didasarkan pada tanggapantanggapan pembaca terhadap karya sastra. Teeuw menegaskan bahwa resepsi termasuk dalam orientasi pragmatik. Karya sastra sangat erat hubungannya dengan pembaca, karena karya sastra ditujukan kepada kepentingan pembaca sebagai menikmat karya sastra. Selain itu, pembaca juga yang menentukan makna dan nilai dari karya sastra, sehingga karya sastra mempunyai nilai karena ada pembaca yang memberikan nilai (Pradopo, 2007, hal. 207)

Pradopo mengemukakan bahwa penelitian resepsi dapat dilakukan dengan dua cara, yaitu secara sinkronis dan diakronis. Penelitian sinkronis merupakan penelitian resepsi terhadap sebuah teks sastra dalam masa satu periode. Penelitian ini menggunakan pembaca yang berada dalam satu periode. Sedangkan penelitian diakronis merupakan penelitian resepsi terhadap sebuah teks sastra yang menggunakan tanggapantanggapan pembaca pada setiap periode. (Pradopo, 2007, hal. 210-211)

Teori resepsi tidak hanya memahami bentuk suatu karya sastra dalam bentangan historis berkenaan dengan pemahamannya. Teori menuntut bahwa sesuatu karya individu menjadi bagian rangkaian karya lain untuk mengetahui arti dan kedudukan historisnya dalam konteks pengalaman kesastraannya. Pada tahapan sejarah resepsi karya sastra terhadap sejarah sastra sangat penting, yang terakhir memanifestasikan dirinya sebagai proses resepsi pasif yang merupakan bagian dari pengarang. Pemahaman berikutnya dapat memecahkan bentuk dan permasalahan moral yang ditinggalkan oleh karya sebelumnya dan pada gilirannya menyajikan permasalahan baru.

Resepsi sastra merupakan aliran sastra yang meneliti teks sastra dengan mempertimbangkan pembaca selaku pemberi sambutan atau tanggapan. Dalam memberikan sambutan dan tanggapan tentunya dipengaruhi oleh faktor ruang, waktu, dan golongan sosial. Secara definitif resepsi sastra berasal dari kata recipere (Latin), reception (Inggris), yang diartikan sebagai penerimaan atau penyambutan pembaca. Dalam arti luas resepsi diartikan sebagai pengolahan teks, cara-cara pemberian makna terhadap karya sehingga dapat memberikan respon terhadapnya. Respon yang dimaksudkan tidak dilakukan antara karya dengan seorang pembaca, melainkan pembaca sebagai proses sejarah, pembaca dalam periode tertentu (Ratna, 2009, hal. 165)

Teori resepsi berpengaruh besar pada cara-cara studi literer yang kemudian banyak dikerjakan, tetapi jalur yang dieksplorasikan ternyata tidak terbukti menjadi seterbuka dan seproduktif seperti diimpikan pada mulanya. Hal tersebut menjadi benar saat teori resepsi dikonfrontasikan dengan keberagaman posisi yang diasosiasikan dengan strukturalis, postrukturalis, atau gerakan avantgarde lain. Dalam teori-teori itu ditunjukkan bagaimana perkembangbiakan wacana yang menentang cara yang dominan dalam mempertimbangkan genre sastra, yang seringkali lebih radikal dan tidak selalu lebih produktif. Oleh karena itu, empat wilayah reseptif yang meliputi teks, pembaca, interpretasi, dan sejarah sastra, perlu direfleksikan kembali agar perbedaan ramifikasi dan limitasinya dengan kecenderungan lain dalam kritik sastra kontemporer menjadi lebih tampak. 
Adapun Sejarah teori sastra dimulai dari ontologi mengenai teori resepsi sastra oleh Rainer Warning (1975) yang memasukkan karangan sarjana-sarjana dari Jerman. Sarjana pertama yang karangannya dimuat oleh Warning adalah penelitian Leo Lowenthal sebelum Perang Dunia Kedua yang mempelajari penerimaan terhadap karya-karya Dostoyevski di Jerman. Tujuan penelitiannya adalah untuk mengetahui pandangan umum di Jerman ketika itu, dan bisa dikatakan bahwa ini juga merupakan pandangan dunia. Walaupun penelitian Lowenthal termasuk dalam penelitian sosiologi sastra, tetapi ia telah bertolak dari dasar yang kelak menjadi dasar teori resepsi sastra. Berdasarkan hasil penelitian Lowenthal ini, Warning memberikan konsep bahwa dalam teori resepsi sastra terhimpun sumbangan pembaca yang menentukan arah penelitian ilmu sastra yang mencari makna, modalitas, dan hasil pertemuan anatara karya dan khalayak melalui berbagai aspek dan cara (Junus, 1985, hal. 29).

Selanjutnya, Warning memasukkan karangan dua sarjana dari Jerman, yakni Ingarden dan Vodicka. Ingarden berbicara tentang kongkretisasi dan rekonstruksi. Berangkat dari hakikat suatu karya yang penuh dengan ketidakpastian estetika, hal ini bisa dipastikan melalui kongkretisasi, sedangkan ketidakpastian pandangan dapat dipastikan melalui rekonstruksi, kedua hal ini dilakukan oleh pembaca. Vodicka juga berangkat dari karya. Karya dilihat sebagai pusat kekuatan sejarah sastra. Pembaca bukan hanya terpaut oleh kehadiran karya sastra, tetapi juga oleh penerimaannya. Dalam menganalisis penerimaan suatu karya sastra, kita harus merekonstruksi kaidah sastra dan anggapan tentang sastra pada masa tertentu. Selanjutnya melakukan studi tentang kongkretisasi karya sastra, dan terakhir mengadakan studi tentang keluasan/kesan dari suatu karya ke dalam lapangan sastra/bukan sastra.

\section{Konsep Teori Resepsi}

Perkembangan resepsi sastra lebih bersemangat setelah munculnya pikiran-pikiran Jausz dan Iser yang dapat dianggap memberikan dasar teoretis dan epistemologis. Tumpuan perhatian dari teori sastra akan diberikan kepada teoriyang mereka kembangkan.

Jausz memiliki pendekatan yang berbeda dengan Iser tentang resepsi sastra, walaupun keduanya sama-sama menumpukan perhatian kepada keaktifan pembaca dalam menggunakan imajinasi mereka. Jausz melihat, a) bagaimana pembaca memahami suatu karya seperti yang terlihat dalam pernyataan/penilaian mereka dan, b) peran karya tidak penting lagi. Yang terpenting di sini yaitu aktifitas pembaca itu sendiri. Sedangkan Iser, a) lebih terbatas pada adanya pembacaan yang berkesan tanpa pembaca perlu mengatakanannya secara aktif dan, b) karya memiliki peranan yang cukup besar. Bahkan kesan yang ada pada pembaca ditentukan oleh karya itu sendiri (Junus, 1985, hal. 49)

Mengadopsi teori resepsi terhadap teks, yang dikembangkan oleh Ahmad Rafiq, resepsi terhadap teks itu tebagi tiga (1) resepsi eksegesis, yakni menafsir makna, (2) resepsi estetis, menjadikannya sebagai entitas estetika atau mendekatinya secara estetis, dan (3) resepsi fungsional yang berakhir secara praksis dan memuat nilai performatif (Rafiq, 2014, hal. 144-154) Jadi pengabdian yang berbasis riset ini menggunakan teori yang dikembangkan oleh AhmadRafiq dalam menilai pemahaman masyarakat terhadap fatwa MUI dan surat edaran pemerintah terkait pencegahan penyebaran virus Covid-19.

\section{Implikasi Lapangan}

Masjid memiliki peran penting di agama Islam, betapa tidak selain sebagai tempat ibadah berupa shalat lima waktu, masjid juga merupakan tempat berkomunikasinya sesama muslim, karena adanya interaksi sesama. Tidak jarang di masjid dipertemukannya seseorang dengan orang lain yang belum dikenal sebelumnya. Masjid dijadikan tempat musyawarah untuk memutuskan hal-hal yang berkenaan dengan agenda-agenda sosial kemasyarakatan yang ada di sekitaran lokasi masjid tersebut, bahkan masjid juga di era modern juga dikaitkan dengan fasilitas pengobatan seperti klinik, fasilitas pendidikan seperti Taman Pengajian al-Qur'an (TPQ) dan Pendidikan Diniyah Takmiliyah Awaliyah 
(PDTA). Tidak hanya itu, masjid-masjid juga menyediakan warung koperasi berbelanja bagi para jamaah dan masyarakat, hal ini tentu akan menambah pendapatan masjid, di tempat yang lain masjid juga menyediakan penginapan yang diperuntukan untuk musafir yang membutuhkan tempat beristirahat. Hal ini tentu adalah sebuah kebijakan dalam rangka mengimplementasikan firman Allah SWT yang mengisyaratkan untuk memakmurkan masjid.

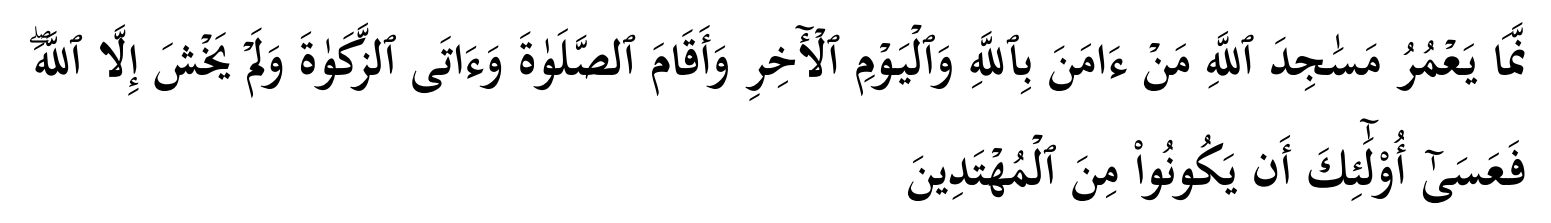

"Hanya yang memakmurkan masjid-masjid Allah ialah orang-orang yang beriman kepada Allah dan hari Kemudian, serta tetap mendirikan shalat, emnunaikan zakat dan tidak takut (kepada siapapun) selain kepada Allah, Maka merekalah orang-orang yang diharapkan Termasuk golongan orang-orang yang mendapat petunjuk" (at-Taubah: 18).

Di masa lalu fungsi masjid sudah beragam, semisal masjid Nabawi. Para sejarawan mencatat tidak kurang dari sepuluh peranan yang telah diemban oleh Masjid oleh masjid Nabawi, diantaranya adalah: 1 . Sebagai tempat ibadah (shalat, zikir), 2. Tempat konsultasi dan komunikasi (masalah ekonomi-sosial budaya), 3. Tempat pendidikan, 4. Tempat santunan sosial, 5. Tempat latihan militer dan alat-alatnya, 6. Tempat pengobatan korban perang, 7. Tempat perdamaian dan pengadilan sengketa, 8. Aula dan tempat menerima tamu, 9. Tempat menawan tahanan, 10. Pusat penerangan atau pembelaan agama. (Shihab, 2007, hal. 610)

Dari sekian banyak yang disebutkan di atas sepertinya peran masjid dimasa sekarang tidak sebanyak masa lalu karena sudah adanya lembaga-lembaga khusus yang dibangun untuk memfokuskan kegiatan tersebut. Tapi paling tidak masjid tetap menjadi berkumpulnya sejumlah orang di dalamnya, perkumpulan itu baik berupa shalat berjamaah, bermusyawarah serta melakukan proses pendidikan dan pengajaran. Perkumpulan semacam ini dimasa pandemi tentu tidak diperbolehkan karena berisiko penularan virus antara satu orang kepada orang lain. Salah satu lembaga yang mengeluarkan amaran untuk tidak boleh berkumpul dalam konteks ibadah dan maupun acara keagamaan khsususnya Islam adalah Majelis Ulama Indonesia (MUI). Majelis Ulama Indonesia (MUI) yang notabenenya sebagai tempat berkumpulnya orang-orang yang mempunyai pengetahuan agama lebih baik dari kalangan masyarakat muslim, yang anggotanya berlatar belakang sebagai sarjana muslim di bidang agama maupun mempunyai kepakaran dibidang lainnya, serta merupakan lembaga keagamaan Islam tempat bertanyanya umat terhadap perkara-perkara yang membutuhkan hukum keagamaan. Dari permasalahan yang ada, Majelis Ulama Indonesia (MUI) mengeluarkan pendapatnya yang disebut fatwa, fatwa tersebutlah kemudian yang menjadi landasan untuk masyarakat untuk melakukan pekerjaan itu. Pemerintah pun merujuk kepada lembaga ini apabila ingin mengambil keputusan terkait masalah keagamaan Islam.

Dalam masalah penyelenggaraan ibadah dimasa Covid-19 ini, MUI mengeluarkan fatwa No. 14 Tahun 2020, fatwa itu kemudian diturunkan lagi setingkat MUI Provinsi dan MUI kabupaten ataupun kota. Khususnya di kota Tanjugpinang, MUI provinsi Kepulauan Riau mengeluarkan tausiah tertanggal 25 maret 2020. Dalam tausiah ini MUI Provinsi Kepulauan Riau meminta agar pengelola masjid tidak mengadakan shalat lima waktu serta mengganti shalat jumat di rumah masing-masing. Pemerintah kota Tanjung Pinang sendiri mengeluarkan dua surat edaran dalam mengantisipasi kerumuman masa semasa pandemi yang didalamnya juga memuat tentang aturan beribadah. Surat edaran pertama tertanggal 23 Maret 2020 pada ketentuan dua (II) poin kelima menyebutkan "Penyelenggaraan kegiatan ibadah keagamaan agar mematuhi 
fatwa/ arahan/ keputusan dari pemimpin umat agama masing-masing". ${ }^{1}$ Surat edaran kedua tertanggal 30 Maret 2020 tentang himbauan pencegahan penyebaran Covid-19 di masjid, surau dan musholla pada poin satu, dua dan tiganya menghimbau agar tidak melakukan aktivitas apapun di tempat ibadah masjid, surau dan musholla. ${ }^{2}$

Walaupun fatwa MUI dan surat edaran Pemerintah kota Tanjungpinang sudah dikeluarkan tapi fenomena di masyarakat masih ada masjid-masjid yang mengadakan aktivitas ibadah seperti shalat lima waktu dan shalat jum'at. Ada juga memang yang menutup masjid hanya pada bagian depannya saja, tapi pintu samping dibuka, seolah-olah dari depan terlihat tidak ada aktivitas tapi ternyata aktivitas shalat tetap dilakukan. Fenomena lain yang juga timbul adalah adanya silang pendapat mengenai penyelenggaraan ibadah di masjid antara sesama pengurus masjid. Perselisihan juga terjadi antara pengurus yang ingin menutup masjid sementara waktu guna menghindari kerumuman masyarakat dengan jamaah yang ingin tetap melaksanakan ibadah di masjid. Maka pengetahuan terkait fatwa MUI dan surat edaran menjadi sangat urgen karena bisa menjadi legal standing bagi pengurus masjid untuk menutup tempat ibadah sementara waktu dan sekaligus menambah pemahaman pengurus dan jamaah terkait penyelenggaraan ibadah dimasa pandemi beradapada frekuensi yang sama, dengan begitu maka perpecahan dapat dihindarkan.

Guna membantu membantu mensosialisasikan fatwa dan surat edaran pemerintah kota Tanjungpinang sekaligus dalam rangka mengetahui resepsi masyarakat terkait fatwa MUI, maka tim pengabdi melakukan kegiatan sosialisasi ke masjid-masjid yang sudah ditentukan. Tim pengabdi menggali data terkait pemahaman masyarakat terhadap fatwa MUI tentang penyelenggaraan ibadah dalam situasi terjadinya wabah Covid-19. Untuk mewujudkan hal tersebut tim melakukan beberapa hal di antranya. Pertama, mengadakan wawancara dengan mengajukan beberapa pertanyaan kepada pengurus masjid untuk menggali pengetahuan dan pemahaman mereka terkait fatwa MUI No. 14 Tahun 2020 dan surat edaran pemerintah sekaligus resepsi mereka tentang fatwa dan edaran tersebut. Kedua, mengadakan penyuluhan terkait fatwa MUI dan surat edaran sebagai upaya mengurangi tingkat penyebaran virus covid 19 di klister rumah ibadah. Ketiga, membagikan buku "Fikih Pandemic Beribah Di masa Wabah" dan kopian fatwa MUINo. 14 Tahun 2020, tausiyah MUI Kepulauan Riau, Himbauan DMI kota Tanjungpinang serta Surat Edaran Walikota No. 440 tertanggal 30 Maret 2020.

Untuk selengkapnya berikut adalah alur gambaran pelaksanaan pengabdian yang dilakukan:

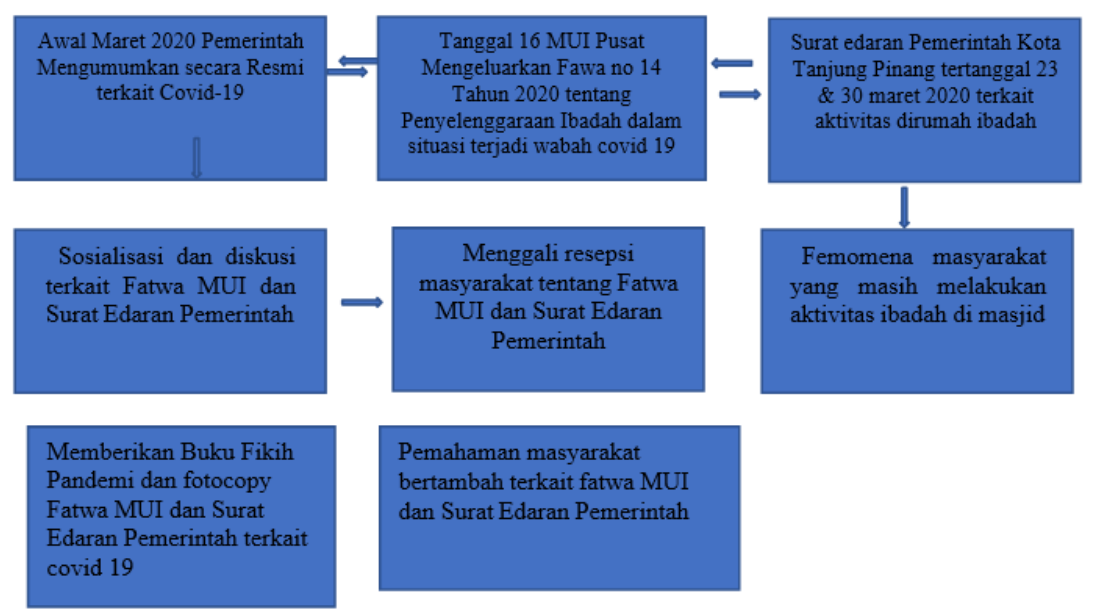

Gambar 3. Alur pelaksanaan pengabdian

${ }^{1}$ Lihat surat edaran Walikota Tanjungpinang Nomor: 4432/400/1/2020 tentang pengaturan penyelenggaraan kegiatan operasional tempat usaha dan kegiatan sosial masyarakat tertentu dalam upaya kewaspadaan terhadap penularan infeksi corona virus disease (Covid-19)

2 Lihat surat edaran Walikota Tanjungpinang No 440/442/1.1.03/2020 tentang himbauan pencegahan penyebaran Covid-19 di masjid, Surau dan Musholla 
Berikut adalah dokumentasi terkait pelaksanaan hal tersebut:
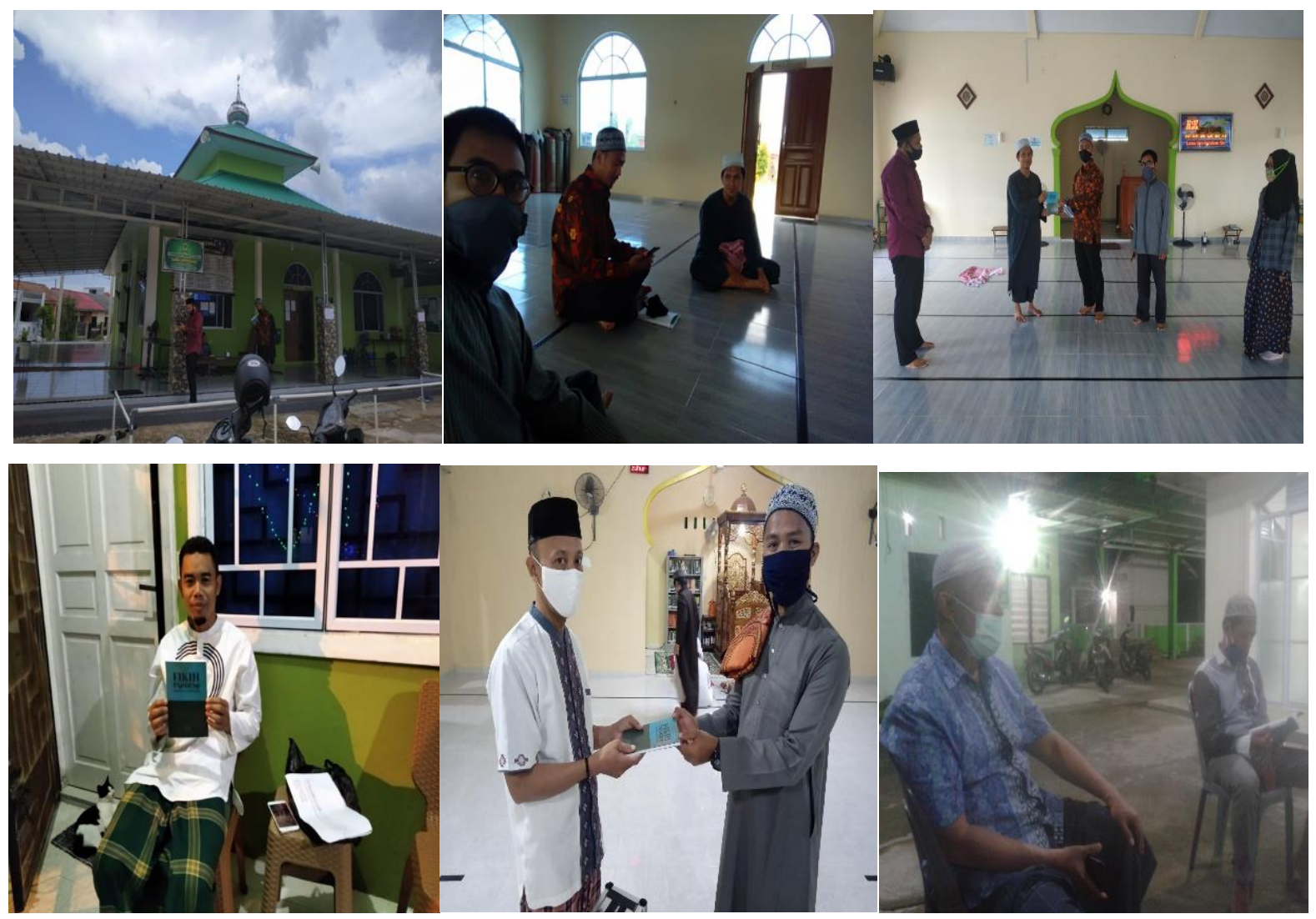

Gambar 4. Dokumentasi pengabdian masyarakat

Dari data yang didapatkan tim bahwa perihal mengenai fatwa MUI dan Edaran pemerintah mereka sudahmengetahuinya namun hanya $20 \%$ saja yang membacanya selebihnya belum membacanya, ketika ditanya apakah ada anggota MUI daerah yang mensosialisasikan, seluruh pengurus masjid menjawab belum ada yang mensosialisasikannya. Dari wawancara juga pihak pengurus mengaprisiasi serta mengucapkan terimakasih karena mereka mendapatkan pengetahuan serta pemahaman terkait aturan beribadah dimasa pandemi sekaligus sebagai bahan penguat untuk pengurus melalukan penutupan sementara rumah ibadah.

Sedangkan data yang kami dapatkan berdasarkan hasil wawancara terkait tentang resepsi pengurus mengenai fatwa MUI dan surat edaran dengan mengaca pada teori resepsi yang dikembangkan oleh Ahmad Rafiq, tim mendapatkan dari perspektif resepsi eksegesis bahwa fatwa MUI dan surat edaran itu ada dua pendapat: pertama, Keputusan yang sifatnya himbauan tanpa mengikat dan kedua, Keputusan yang sifatnya himbauan dan mengikat. Sekitar 70 persen koresponden berpendapat pertama selebihnya berpendapat kedua. Sedangkan untuk resepsi fungsional, pengurus masjid menjadikan fatwa MUI dan Surat Edaran sebagai bahan (alasan) untuk menutup sementara fungsi masjid sebagai tempat ibadah. Berikut adalah gambar tentang resepsi fungsional tersebut. 

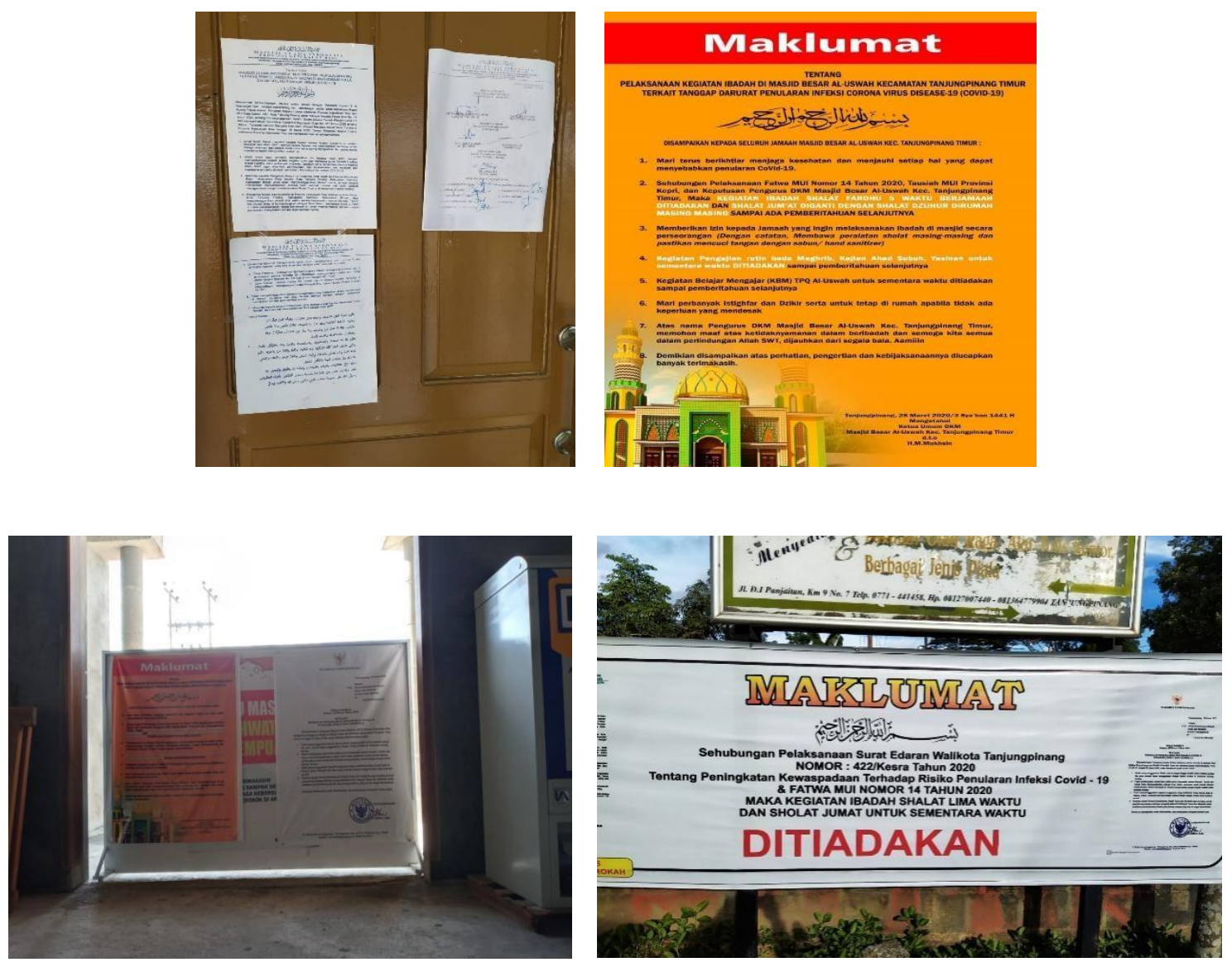

Gambar 5. Imbauan shalat di rumah

\section{Kesimpulan}

Dari hasil pengabdian yang berbasis penelitian yang dilakukan oleh penulis, maka disimpulkan sebagai berikut:

1. Adanya berbagai resepsi terhadap fatwa MUI dan edaran pemerintah dalam konteks eksegesis misalnya adalah memandang sebagai himbauan yang sifatnya tidak mengikat dan yang mengikat. Dan sekaligus berfungsi sebagai alat untuk mengingatkan jamaah agar tidak melakukan shalat dimasjid untuksementara waktu.

2. Adanya peningkatan pemahaman terhadap Fatwa MUI secara utuh dari sebelumnya karena sudah diterangkan

3. Adanya peningkatan pemahaman dalil shalat beribadah semasa pandemi karena sudah dibekali dengan buku.

\section{Saran}

Artikel ini merupakan ringkasan dari laporan PKM berbasis riset. Adapun pihak-pihak yang terlibat dalam kegiataan ini adalah Direktorat Pendidikan Tinggi Keagamaan Islam, Direktorat Jendra Pendidikan Islam, Kementrian Agama RI yang membiayai secara penuh LP3M Sekolah Tinggi Agama Islam Negeri (STAIN) Sultan Abdurrahman Kepulauan Riau, perwakilan pengurus masjid dikecamatan Tanjungpinang Timur. Tanpa bantuan mereka PKM ini tidak berjalan sesuai dengan harapan. Oleh karena itu, kepada semua pihak yang terlibat tim PKM menghaturkan terimakasih. 


\section{Referensi}

Kompas. (2020, Maret 9). kompas.com. Retrieved April 2020, from https://nasional.kompas.com/read/2020/03/09/05280011/kronologi-dan-urutan-munculnya-6-orangpositif-virus-corona-di-indonesia

Al-Sabuni, M. '. (2001). Safwat al-Tafsir. Beirut: Dar Al-Fikr.

MUI. (2020, Maret 16). https://mui.or.id/wp-content/uploads/2020/03/Fatwa-tentangPenyelanggaran- Ibadah-Dalam-siatuasi-Wabah-COVID-19.pdf. Retrieved April 2020, from Website MUI: mui.or.id

Kumparan. (2020). https://kumparan.com/kumparannews/virus-corona-diduga-munculpertama-kali-pada- 17-november-2019-di-hubei-1t11BcMNz73/full. Retrieved April 9, 2020, from Kumparan Website: Kumparan.com

JDIH. (2020, April 9). https://jdih.menpan.go.id/puu-994-Surat\%20Edaran\%20Menpan.html. Retrieved from JDIH Website: jdih.menpan.go.id

Sastriyani, S. H. (2001). Karya Sastra Perancis Abad ke-19 Madame Bovary dan Resepsinya di Indonesia. Jurnal Humaniora, XIII(03), 252-259.

Ratna, N. K. (2009). Metode dan Teknik Penelitian Sastra. Yogyakarta: Pustaka Pelajar.

Walidin, M. (2007, Desember). http://mwalidin.blogspot.com/2007/12/seksualitas-dalam-novel-indonesia.

Retrieved April 2020, from Muhammad Walidin Blog: http://mwalidin.blogspot.com

Pradopo, R. D. (2007). Beberapa Teori Sastra: Metode Kritik dan Penerapannya. Yogyakarta: Pustaka Pelajar.

Ratna, N. K. (2009). Metode dan Teknik Penelitian Sastra. Yogyakarta: Pustaka Pelajar.Junus, U. (1985). Resepsi Sastra: Sebuah Pengantar. Jakarta: Gramedia.

Rafiq, A. (2014). he Reception of the Qur'an in Indonesia; A Case Study of the Place of the Qur'an in a Non-Arabic Speaking Community. Philadelphia: Disertasi Ph.D. The Temple University Graduate Board.

Muhid dkk, A. (2018). Perubahan Perilaku Open Defecation Free (ODF) melalui Program Sanitasi Total Berbasis Masyarakat (STBM) di Desa Babad Kecamatan Kedungadem Kabupaten Bojonegoro. Engagemen: Jurnal Pengabdian Kepada Masyarakat, 2(1), 99-119.

Shihab, M. (2007). Wawasan Al-Qur'an: Tafsir Tematik atas Pelbagai Persoalan Umat. Bandung: Mizan 